\title{
PREVALÊNCIA SOROLÓGICA DA MAEDI-VISNA EM REBANHOS OVINOS DA MICRORREGIÃO DE JUAZEIRO - BAHIA POR MEIO DO TESTE DE IMUNODIFUSÃO EM GEL DE ÁGAR
}

\author{
Priscila Martinez Martinez ${ }^{1}$, Joselito Nunes Costa², Thiago Sampaio de Souza ${ }^{3}$, Carla Caroline \\ Valença de Lima ${ }^{4}$, Antônio de Oliveira Costa Neto 5 , Raymundo Rizaldo Pinheiro ${ }^{6}$
}

1 - Médica Veterinária, Companhia de Desenvolvimento dos Vales do São Francisco e Parnaíba (CODEVASF).

2 - Professor Doutor do Departamento de Patologia e Clínicas da Escola de Medicina Veterinária da Universidade Federal da Bahia EMV/UFBA - joselitonc@yahoo.com.br

3 - Doutorando do Programa de Pós-Graduação em Ciência Animal nos Trópicos - UFBA.

4 - Mestranda do Programa de Pós-Graduação em Ciência Animal nos Trópicos - UFBA.

5 - Professor do Curso de Ciências Biológicas da Universidade Estadual de Feira de Santana. 6 - Pesquisador Doutor da Embrapa Caprinos e Ovinos.

\section{RESUMO}

A introdução de novas raças, com o objetivo de aumentar a produtividade, levou à alteração do perfil sanitário dos rebanhos. Dentre as enfermidades introduzidas no Brasil, destacam-se as lentiviroses de pequenos ruminantes (LVPR), representadas pela artrite-encefalite caprina (CAE) e pela maedi-visna (MV). Devido à importância econômica da ovinocultura para a microrregião de Juazeiro-Bahia e à escassez de dados sobre a lentivirose em ovinos, buscou-se obter a prevalência da MV. Foram avaliados 919 soros por imunodifusão em gel de ágar
(IDGA). As amostras foram colhidas nos oito municípios que compõem essa microrregião (Juazeiro, Sento Sé, Sobradinho, Pilão Arcado, Campo Alegre de Lourdes, Remanso, Casa Nova e Curaçá), conforme a representatividade de cada município no total de animais. Constatou-se que 0,34\% (4/919) dos ovinos amostrados apresentaram reação positiva no IDGA. Concluiu-se com esse resultado que a MV ocorre na microrregião estudada, com baixa prevalência, provavelmente pela predominância de animais de raças localmente adaptadas.

PALAVRAS-CHAVE: Anticorpos; IDGA; Lentivirus; ocorrência.

\section{SEROLOGICAL PREVALENCE OF MAEDI VISNA IN SHEEP HERDS IN THE MICROREGION OF JUAZEIRO - BAHIA, BY AGAR GEL IMMUNODIFFUSION}

(AGID).

The introduction of new breeds, aiming at increasing productivity, caused the change in the health profile of herds. Among the diseases introduced in Brazil lentiviroses of small ruminants (LVPR) stand out, represented by caprine arthritis encephalitis (CAE) and the maedi-visna (MV). In order to obtain data concerning the presence of maedi visna (MV) in sheep herds in the microregion of Juazeiro, Bahia, 919 serum samples were evaluated by agar gel immunodiffusion (AGID). The samples were collected in eight cities that make up this 
microregion (Juazeiro, Sento Sé, Sobradinho, Pilão Arcado, Campo Alegre Lourdes, Remanso, Casa Nova and Curaçá) considering how representative each municipality is within the totalilty of animals. It was observed that $0.34 \%$ of the sampled sheep showed

KEYWORDS: AGID; antibodies; Lentivirus; occurrence.

\section{INTRODUÇÃO}

A origem do nome maedi-visna (MV) é islandesa. Maedi significa dispneia, em consequência da pneumonia intersticial progressiva crônica, e visna significa desorientação causada pela leucoencefalite (DAWSON, 1987). O vírus da maedi-visna (MVV) foi isolado e caracterizado como causador de uma epidemia de pneumonia progressiva (maedi) acompanhada por paralisia progressiva (visna) em um levantamento realizado na Islândia entre 1939 e 1952, no qual 150 mil animais morreram e 650 mil foram sacrificados para controle da doença (SIGURDSSON, 1954).

O MVV pertence à família Retroviridae, subfamília Orthoretrovirinae, gênero Lentivirus, grupo lentivírus de pequenos ruminantes (LVPR) (RÁCZ, 2005; ICTV, 2008). Vários outros vírus de importância veterinária e humana também estão incluídos nesse gênero, como o vírus da imunodeficiência humana (HIV), bovina (BIV), felina (FIV), símia (SIV) e vírus da anemia infecciosa equina (AIEV) (ICTV, 2008). A MV é uma doença infecciosa caracterizada por um longo período de incubação que provoca, principalmente em ovinos adultos, uma infecção multissistêmica, muitas vezes assintomática, de evolução lenta, tendo por resultado uma doença degenerativa crônica (BRODIE et al., 1998).

$\mathrm{O}$ vírus infecta células da linhagem monócito-macrófago, aderindo-se a elas pela ligação da glicoproteína do seu envelope a receptores específicos na membrana celular. Após a penetração, o vírus replica seu genoma RNA via um pró-virus intermediário DNA, que se integra ao DNA cromossômico das células infectadas. Na maioria das vezes, a replicação fica restrita e não prossegue além da síntese do pró-vírus, sendo esse um mecanismo que resulta na persistência da infecção no organismo (PASICK, 1998; RADOSTITS et al., 2002; QUINN et al., 2005). Como o sítio de eleição para a replicação do vírus é o macrófago, as secreções pulmonares e o leite contendo macrófagos infectados são as principais vias de eliminação, positive reaction in the AGID. It was concluded that the MV occurs with low prevalence in the studied microregion, probably due to the predominance of locally adapted breeds.

propiciando a transmissão natural. Há persistência e replicação do vírus na presença de respostas imunes específicas, resultando no desenvolvimento de lesões imunomediadas em vários sistemas orgânicos e em hiperplasia linfocítica. Dessa forma, os macrófagos infectados ficam envoltos por resposta inflamatória, criando-se um núcleo de agregação de células mononucleares, principalmente nos pulmões, articulações, glândula mamária e sistema nervoso central (DAWSON, 1987; GEORGE \& SMITH, 2006).

O processo inflamatório é insidioso e subclínico, prolongando-se por meses ou anos. Os animais enfermos geralmente têm acima de três anos. Ocorrem quatro formas clínicas da doença: respiratória, nervosa, articular e mastite (MOOJEN, 2001). Essas alterações podem ocorrer de forma conjunta ou independente (DAWSON, 1987; BRODIE et al., 1998).

O lentivírus ovino (LVO) causa com maior frequência sintomas respiratórios, caracterizados por dispneia, intolerância ao exercício, emagrecimento crônico e quadro secundário de pneumonia, devendo ser diferenciado de adenomatose pulmonar (AP) (MOOJEN, 2001; QUINN et al., 2005). O relato de sintomas nervosos foi significativo no surto ocorrido na Islândia. Entretanto, essa é uma forma rara de manifestação clínica da doença. Se as lesões neurológicas forem suficientemente severas para produzir a doença, os sinais clínicos observados são paralisia ascendente com incoordenação progressiva evoluindo durante semanas ou meses. As lesões neurológicas caracterizam-se por meningite linfocítica com desmielinização e gliose (DAWSON, 1987).

Os métodos de diagnóstico para essa enfermidade fundamentam-se em provas para a detecção direta do vírus ou do seu material genético ou, ainda, de forma indireta pela detecção de anticorpos. $\mathrm{O}$ isolamento viral, a microscopia eletrônica, a reação em cadeia de polimerase (PCR) e a hibridização in situ são os principais métodos utilizados para a detecção direta do LVPR. A sorologia é um método indireto de diagnóstico que funciona de forma satisfatória em decorrência das características próprias dessas enfermidades, principalmente pela sua forma persis- 
tente de infecção, podendo ser diagnosticada por técnicas como imunodifusão em gel de ágar (IDGA), imunofluorescência indireta, enzyme-linked immunosorbent assay (ELISA), dot-blot e immunoblotting (PINHEIRO et al., 2001b).

No Brasil, a primeira identificação de ovinos positivos no IDGA para maedi-visna (MV) ocorreu em 1989, no Rio Grande do Sul, em propriedades com histórico de importações de animais. Foram testados 267 animais de 16 municípios do estado, sendo que $28(10,48 \%)$ amostras foram positivas (DAL PIZZOL et al., 1989). Diversos estudos epidemiológicos das lentiviroses de pequenos ruminantes no Brasil têm demonstrado a disseminação dos lentivírus em várias regiões (ALMEIDA et al., 2001; PINHEIRO et al., 2001a; ALMEIDA et al., 2003; PINHEIRO et al., 2004). A presença do MVV até 1999 era restrita a estados do sul do Brasil, mas recentemente resultados sorológicos têm indicado a presença do vírus em alguns estados do nordeste (SOUZA et al., 2007).

Baseando-se nas evidências de resultados sorológicos positivos para a MV observados em estados nordestinos, na escassez de dados dessa enfermidade na Bahia e na importância sócio-econômica da ovinocultura no Vale do São Francisco, objetivou-se pesquisar a prevalência dessa lentivirose no rebanho ovino da Microrregião de Juazeiro, Bahia.

\section{MATERIAL E MÉTODOS}

Este levantamento epidemiológico foi realizado na Região Nordeste do Brasil, Estado da Bahia,
Microrregião de Juazeiro, que é subdividida em oito municípios: Juazeiro, Pilão Arcado, Campo Alegre de Lourdes, Remanso, Sento Sé, Casa Nova, Sobradinho e Curaçá.

O efetivo ovino da Bahia é de 3.028.507 cabeças (IBGE, 2011), segundo maior rebanho do país, composto basicamente por animais sem raça definida (SRD) e raças brasileiras localmente adaptadas. O sistema de exploração dos ovinos caracteriza-se predominante pelo pastoreio extensivo durante o dia e alguma proteção do ambiente natural durante a noite. Existe na microrregião estudada um sistema de criação conhecido como "fundo de pasto", uma característica regional que não ocorre em nenhum outro local do Brasil. Neste sistema, as propriedades não são registradas, não existe divisão de pastagens, são áreas comuns onde os animais são criados de forma coletiva e identificados com corte na orelha, sendo que cada proprietário tem uma marca padrão, não havendo identificação individual para os animais.

O número mínimo de amostras (n) foi calculado, considerando uma prevalência esperada de $10 \%$, baseado na média de prevalências obtidas em estados brasileiros, com erro amostral de $20 \%$ e grau de confiança de $95 \%(z=1,96)$, utilizando-se a fórmula de ASTUDILLO (1979), com dados do Instituto Brasileiro de Geografia e Estatística (IBGE) disponíveis em 2005.

De acordo com o cálculo, o número mínimo de amostras a serem colhidas teria que ser de 863 . Essas foram distribuídas entre os oito municípios da Microrregião de Juazeiro, proporcionalmente à participação de cada um deles no rebanho total da microrregião (Tabela 1).

Tabela 1. Rebanho de cada município, percentual de participação de cada município no total de animais da microrregião e número mínimo de amostras a serem colhidas

\begin{tabular}{lccc}
\hline \multicolumn{1}{c}{ Municipio } & $\begin{array}{c}\text { Número de animais } \\
\text { (IBGE, 2005) }\end{array}$ & $\begin{array}{c}\text { \% de participação do municipio no } \\
\text { rebanho da microrregião }\end{array}$ & $\begin{array}{c}\mathrm{N}^{\circ} \text { minimo de amostras / } \\
\text { municipio }\end{array}$ \\
\hline Juazeiro & 162781 & 22,56 & 85 \\
Sobradinho & 6302 & 0,87 & 87 \\
Curaçá & 72822 & 10,09 & 152 \\
Casa Nova & 127144 & 17,62 & 79 \\
Campo Alegre de Lourdes & 65646 & 9,1 & 74 \\
Pilão Arcado & 61501 & 8,52 & 207 \\
Remanso & 172883 & 23,96 & 63 \\
Sento Sé & 52366 & 7,26 & 865 \\
\hline \multicolumn{1}{c}{ Total } & 721445 & $100 \%$ & \\
\hline
\end{tabular}


Foram visitadas 58 propriedades na Microrregião de Juazeiro, onde está concentrada a maior representatividade da ovinocultura do estado. O total de amostras ultrapassou o mínimo pois, em virtude da dificuldade de acesso às comunidades rurais e a possibilidade de hemólise das amostras, optou-se por colher algumas amostras a mais, totalizando então 919, distribuídas da forma apresentada na Tabela 2 .

Tabela 2. Número de propriedades e amostras colhidas por município da microrregião

\begin{tabular}{ccc}
\hline Municipio & $\begin{array}{c}\mathrm{N}^{\circ} \text { de propriedades para } \\
\text { collheitas }\end{array}$ & $\begin{array}{c}\mathrm{N}^{\circ} \text { de amostras colhidas/ } \\
\text { municipio }\end{array}$ \\
\hline Juazeiro & 13 & 200 \\
Sobradinho & 1 & 10 \\
Curaçá & 6 & 95 \\
Casa Nova & 10 & 171 \\
Campo Alegre de Lourdes & 5 & 84 \\
Pilão Arcado & 5 & 80 \\
Remanso & 14 & 211 \\
Sento Sé & 4 & 68 \\
\hline Total & 58 & 919 \\
\hline
\end{tabular}

Após anti-sepsia adequada, as amostras de sangue foram colhidas por venopunção da jugular, usando-se tubos a vácuo com gel ativador de coágulo. Em seguida, após a formação de coágulo, os tubos foram centrifugados a $1600 \mathrm{~g}$ por 10 minutos para a obtenção do soro, que foi acondicionado em tubos tipo eppendorf e estocados a $-20^{\circ} \mathrm{C}$ até a realização dos testes sorológicos. Esses testes foram realizados no Laboratório de Patologia Clínica do Centro Nacional de Pesquisa de Caprinos e Ovinos da Empresa Brasileira de Pesquisa Agropecuária (Embrapa Caprinos e Ovinos), em Sobral - Ceará.

A sorologia para infecção pelo vírus da maedi-visna foi realizada pelo método de imunodifusão em gel de agarose (IDGA), que se baseia na detecção de linhas de precipitação, resultantes da ligação antígeno-anticorpo (PINHEIRO et al., 2006), utilizando-se antígeno nacional produzido no Laboratório de Virologia da Embrapa Caprinos e Ovinos, a partir de sobrenadantes de células de membrana sinovial ovina (MSO) infectadas com o lentivírus da cepa K-1514 (ARAGÃO et al., 2008). O soro-padrão utilizado originou-se de animais fortemente positivos para artriteencefalite caprina (CAE) testados com o reagente comercial americano (Caprine arthritisencephalitis/ovine progressive pneumonia antibody test kit, Veterinary Diagnostic Technology, Inc $®$, USA).

Para a execução da técnica, foi preparado o gel de agarose a $0,9 \%$ em tampão borato. A solução fundida foi distribuída em lâminas lisas de microscopia (4,6mL por lâmina). Essas permaneceram em temperatura ambiente até a solidificação do ágar para posteriormente serem acondicionadas a $4-8^{\circ} \mathrm{C}$. Após 12 horas, o gel foi perfurado em dois locais, com roseta metálica padrão de formato hexagonal que possui sete orifícios (um no centro e seis periféricos). Cada orifício mede $4 \mathrm{~mm}$ de diâmetro, com capacidade de $30 \mu \mathrm{L}$ de soro/antígeno. Os orifícios 1 e 4 foram preenchidos com soropadrão, os orifícios $2,3,5$ e 6 com os soros testes e o central com antígeno (PINHEIRO et al., 2006).

Após o procedimento, as lâminas foram acondicionadas em câmaras úmidas à temperatura de $25^{\circ} \mathrm{C}$. A leitura foi realizada após 48-72 horas, com luz indireta sobre fundo escuro, sendo considerada definitiva a última leitura. Considerou-se como reação positiva a presença de uma linha de precipitação esbranquiçada e uniforme entre o poço teste e o 
antígeno, apresentando identidade com a linha formada pelo soro padrão, e como reação negativa, a ausência de uma linha de precipitação ou linhas sem identidade.

As amostras de soro que demonstraram resultados inconclusivos foram retestadas utilizandose o kit comercial americano, obedecendo-se à seguinte arrumação da roseta: poços 1,3 e 5 foram preenchidos com o soro padrão; 2, 4 e 6 com os soros testes e o central com o antígeno.

\section{RESULTADOS E DISCUSSÃO}

Dos 919 animais testados, 0,34\% (4/919) foram positivos (Tabela 3). Outros levantamentos realizados no Brasil também demonstraram baixa prevalência ou não obtiveram resultados positivos (FERNANDES et al., 2003; ARAÚJO et al., 2004; COSTA et al., 2007).

Tabela 3. Prevalência sorológica da maedi-visna na Microrregião de Juazeiro, BA

\begin{tabular}{ccc}
\hline Muricipio & Número de animais positivos & Prevalência (\%) \\
\hline Juazeiro & 1 & 0,5 \\
Sobradinho & 0 & 0 \\
Curaçá & 0 & 0 \\
Casa Nova & 2 & 1,17 \\
Campo Alegre de Lourdes & 1 & 1,19 \\
Pilão Arcado & 0 & 0 \\
Remanso & 0 & 0 \\
Sento Sé & 0 & 0 \\
\hline Total (Microrregião Juazeiro - BA) & 4 & 0,34 \\
\hline
\end{tabular}

Do total de animais amostrados, 42,7\% estavam com mais de três anos, seguidos por $38,1 \%$ que estavam na faixa etária entre um e três anos e $19,2 \%$ com menos de um ano, sendo que $80,9 \%$ eram fêmeas e 19,1\% eram machos. Neste levantamento, todos os animais soropositivos foram fêmeas acima de um ano (Tabela 4).

Tabela 4. Faixa etária e sexo dos ovinos testados para o vírus maedi-visna na Microrregião de Juazeiro, BA

\begin{tabular}{ccc}
\hline Variảvel & Estrato & \% de participação \\
\hline \multirow{3}{*}{ Faixa etaria } & Menos de 1 ano & 19,2 \\
& De 1 a 3 anos & 38,1 \\
& Mais de 3 anos & 42,7 \\
\hline \multirow{2}{*}{ Sexo } & Fêmea & 80,9 \\
& Macho & 19,1 \\
\hline
\end{tabular}

ARSENAULT et al. (2003), realizando um estudo epidemiológico em Quebec (Canadá), observaram o aumento da soro-prevalência com o aumento da idade dos animais e com o tamanho do rebanho e ressaltaram o fato de a suscetibilidade à transmissão horizontal ser maior com a prolongada exposição. ARAÚJO et al. (2004), entretanto, não observaram diferenças significativas da prevalência da MV nas diferentes faixas etárias pesquisadas na sorologia de ovinos oriundos de abatedouros em Fortaleza, CE.

Provavelmente, a baixa prevalência se deve à predominância de animais SRD e de raças brasileiras localmente adaptadas, sendo importante aumentar a fiscalização na introdução e saída de animais para outros estados sem exames que demonstrem a ausência da infecção para o vírus da MV. Observou-se a presença de ovinos de raças exóticas, como Dorper, White Dorper, Ile de France e Suffolk em $17,5 \%$ das propriedades visitadas, enquanto em $82,5 \%$ ocorreu à predominância de 
ovinos sem raça definida (SRD) ou de raças brasileiras localmente adaptadas (Santa Inês, Somalis, Rabo Largo e Morada Nova) (Tabela 5). Dos animais soropositivos, dois eram sem raça definida e os outros eram mestiços das raças Santa Inês e Somalis (Tabela 6). A presença de anticorpos contra o lentivírus ovino em animais da raça Santa Inês foi registrada anteriormente no nordeste brasileiro por COSTA et al. (2007).
Tabela 5. Presença de raças exóticas nas propriedades visitadas na Microrregião de Juazeiro BA

\begin{tabular}{lcc}
\hline \multicolumn{1}{c}{ Variável } & Ocorrência & Situação (\%) \\
\hline $\begin{array}{l}\text { Presença de } \\
\text { raças exóticas }\end{array}$ & Sim & 17,5 \\
& Não & 82,5 \\
\hline
\end{tabular}

Tabela 6. Características dos animais positivos e das propriedades com ocorrência de animais sororreagentes

\begin{tabular}{|c|c|c|c|c|c|}
\hline \multirow{2}{*}{ Municipios } & \multicolumn{3}{|c|}{ Dados do animal } & \multicolumn{2}{|c|}{ Dados da propriedade } \\
\hline & Raça & Sexo & Idade & Origem do rebanho & Raças observadas \\
\hline Juazeiro & Sem raça definida & Fêmea & Entre 1 e 3 anos & Local (mesmo municipio) & Sem raça definida \\
\hline Casa Nova & Mestiço (Somalis) & Fêmea & Mais de três anos & $\begin{array}{l}\text { Origem nacional (outros } \\
\text { estados e/ou local) }\end{array}$ & $\begin{array}{c}\text { Sem raça definida, } \\
\text { Somalis, Morada Nova e } \\
\text { Santa Inés }\end{array}$ \\
\hline Casa Nova & Sem raça definida & Fêmea & Mais de três anos & $\begin{array}{l}\text { Origem nacional (outros } \\
\text { estados e/ou local) }\end{array}$ & Santa Inês \\
\hline $\begin{array}{l}\text { Campo Alegre de } \\
\text { Lourdes }\end{array}$ & Mestiço (Sarta Inês) & Fêmea & Entre 1 e 3 anos & $\begin{array}{l}\text { Origem nacional (outros } \\
\text { estados e/ou local) }\end{array}$ & Santa Inês e Rabo Largo \\
\hline
\end{tabular}

$\mathrm{Na}$ Islândia, a introdução do MVV ocorreu através da importação de ovinos da raça Karakul originados da Alemanha, quando vários animais morreram ou foram sacrificados para controle da doença (SIGURDSSON, 1954). No Brasil, a primeira identificação de ovinos positivos ocorreu no Rio Grande do Sul em propriedades com histórico de importação. A presença do vírus MV até 1999 era restrita a estados do sul do Brasil onde ocorreram importações de raças européias (DAL PIZZOL et al., 1989). No entanto, levantamentos sorológicos têm indicado a presença do vírus MV em alguns estados nordestinos, onde estão concentrados animais de raças brasileiras localmente adaptadas. O trânsito desses animais para outros estados e a compra eventual de ovinos de raças exóticas levou à introdução do vírus $\mathrm{MV}$ no nordeste (COSTA et al., 2007; SOUZA et al., 2007).

Neste levantamento, nenhum dos animais soropositivos apresentou alterações clínicas. Entretanto, sabe-se que a maedi-visna se caracteriza por longo período de incubação, curso clínico demorado e lentamente progressivo, apresentandose na maioria das vezes na forma subclínica (DAWSON, 1987; BRODIE, 1998; MOOJEN, 2001).

Nos levantamentos realizados no Brasil, observa-se de forma geral baixa prevalência (FERNANDES et al., 2003; COSTA et al., 2007), porém significativa, uma vez que se trata de uma doença com repercussão internacional e que pode trazer consequências econômicas para a ovinocultura nacional. Observa-se também que em alguns estados, como Ceará, foram detectadas elevadas prevalências (ALMEIDA et al., 2003), o que coloca em risco os rebanhos nordestinos que são, na sua maioria, compostos por ovinos deslanados de raça local e sem raça definida (SRD).

Observa-se neste trabalho uma baixa prevalência, porém importante, pela concentração de ovinos nesta região e pelo manejo adotado baseado em baixo controle sanitário. A baixa tecnologia 
implantada, o longo tempo de permanência dos animais no rebanho e a falta de exigência de atestados na compra de novos animais podem contribuir para a disseminação do vírus MV nos planteis do semiárido.

\section{CONCLUSÕES}

A ocorrência de anticorpos contra o vírus da maedi-visna na Microrregião de Juazeiro, Bahia, é de $0,34 \%$, caracterizando uma baixa prevalência, mas apontando para a provável presença do vírus na região. Isso torna necessário um levantamento mais abrangente no estado, contribuindo para a elaboração de um programa sanitário que evite a entrada de animais portadores do vírus e o transporte desses para outras regiões.

\section{AGRADECIMENTOS}

Aos criadores de ovinos da Microrregião de Juazeiro pela disponibilização dos animais para que as colheitas pudessem ser realizadas; à Embrapa Caprinos e Ovinos pela cessão do antígeno e da estrutura laboratorial utilizada para a realização dos exames; ao Banco do Nordeste (BNB) e à Fundação de Amparo a Pesquisa do estado da Bahia (FAPESB) pelo financiamento do Projeto e ao Centro de Desenvolvimento da Pecuária (CDP) pelo apoio técnico às ações realizadas a campo.

\section{REFERÊNCIAS}

ALMEIDA, M. G. A. R.; ANUNCIAÇÃO, A. V. M.; FIGUEIREDO, A. MARTINEZ, T. C. N.; LABORDA, S. S. Dados sorológicos sobre a presença e distribuição da artrite-encefalite caprina (CAE) no Estado da Bahia, Brasil. Revista Brasileira de Saúde e Produção Animal, v. 1, n. 3, p. 78-83, 2001.

ALMEIDA, N. C.; TEIXEIRA, M. F. S.; FERREIRA, R. C. S.; CALLADO, A. K. C.; FROTA, M. N. L.; MELO, A. C. M.; APRIGIO, C. J. L. Deteç̧ão de ovinos soropositivos para Maedi/Visna destinados ao abate na região metropolitana de Fortaleza. Veterinária Notícias, v. 9, n. 1, p. 59-63, 2003.

ARAGÃO, M.A.C.; PINHEIRO, R.R.; ANDRIOLI, A.; ALVES, F.S.F; OLIVEIRA, A.A.F.; TEIXEIRA, M.F.S. Maedi-Visna Vírus: Produção de antígeno, análise protéica e antigênica. Arquivos do Instituto Biológico, v. 75, n. 4, p.423-429, 2008.
ARAÚJO, S. A. C.; DANTAS, T. V. M.; SILVA, J. B. A.; RIBEIRO, A. L.; RICARTE, A. R. F.; TEIXEIRA, M. F. S. Identificação do Maedi-visna vírus em pulmão de ovinos infectados naturalmente. Arquivos do Instituto Biológico, v. 71, n. 4, p. 431-436, 2004.

ARSENAULT, J.; DUBREUIL, P.; GIRARD, C; SIMARD, C.; BÉLANGER, D. Maedi-visna impact on productivity in Quebec sheep flocks (Canada). Preventive Veterinary Medicine, v. 59, p. 125-137, 2003.

ASTUDILLO, V. M. Encuestas por muestreo para estudios epidemiologicos en populaciones animales. Rio de Janeiro: Organización Panamericana de la Salud Centro Panamericano de Fiebre Aftosa, 1979. 60p. (Serie de Manuales Didácticos, 12). Disponível em http://bvs1.panaftosa.org.br/local/File/textoc/SerManDid1 2.pdf. Acesso em abril 2008.

BRODIE, S. J.; DE LA CONCHA-BERMEJILLO, A.; SNOWDER, G. D.; DEMARTINI, J. C. Current concepts in the epizootiology, diagnosis and economic importance of ovine progressive pneumonia in North America: A review. Small Ruminant Research, v. 27, p. 1-17, 1998.

COSTA, L. S. P.; LIMA, P. P.; CALLADO, A. K. C.; NASCIMENTO, S. A.; CASTRO, R. S. Lentivírus de pequenos ruminantes em ovinos Santa Inês: Isolamento, identificação pela PCR e inquérito sorológico no estado de Pernambuco. Arquivos do Instituto Biológico, v. 74, n. 1, p. 11-16, 2007.

DAL PIZZOL, M.; RAVAZZOLO, A.P.; GONÇALVES, I. P. D.; HOTZEL, I.; FERNANDES, J. C. T.; MOOJEN, V. Maedi-Visna: Evidência de ovinos infectados no Rio Grande do Sul, Brasil, 1987-1989. Arquivos da Faculdade de Veterinária da UFRGS, v. 17, p. 65-76, 1989.

DAWSON, M. Pathogenesis of maedi-visna. The Veterinary Record, v. 120.p. 451- 454, 1987.

FERNANDES, M. A.; ARAÚJO, W. P.; CASTRO, R. S. Prevalência da infecção pelo vírus Maedi-Visna em ovinos da microrregião da grande São Paulo, Estado de São Paulo. Ciência Veterinária nos Trópicos, v. 6, n. 1, p. 23-28, 2003.

GEORGE, L. W.; SMITH, M. O. Doenças produzindo sinais corticais - Infecção pelo vírus Maedi-Visna. In: SMITH, B.P. Medicina interna de grandes animais. 3.ed. São Paulo: Manole, 2006. p. 876-877.

IBGE. Instituto Brasileiro de Geografia e Estatística. Pecuária - Rebanho ovino. Disponível em: $<$ http://www.ibge.gov.br> Acesso em 22 fev. 2005.

IBGE. Instituto Brasileiro de Geografia e Estatística. Pecuária - Rebanho ovino. Disponível em: $<$ http://www.ibge.gov.br $>$ Acesso em 22 fev. 2011.

ICTV. International Committee on Taxonomy of Viruses. Disponível em: <http:// www.ncbi.nlm.nih.gov > 
Acesso em 22 abr. 2008.

MOOJEN, V. Maedi-visna dos ovinos. In: RIETCORREA, F.; SCHILD, A.L.; MENDEZ, M.D.C.; LEMOS, R.A.A. Doenças de ruminantes e equinos. 2. ed. São Paulo: Varela, São Paulo, 2001, p.138-144.

OLIVEIRA, M. M. M.; CASTRO, R. S.; CARNEIRO, K. L.; NASCIMENTO, S. A.; CALLADO, A. K. C.; ALENCAR, C. S. A.; COSTA, L. S P. Anticorpos contra lentivírus de pequenos ruminantes em caprinos e ovinos em abatedouros do estado de Pernambuco. Arquivo Brasileiro de Medicina Veterinária e Zootecnia, v. 58, n. 5, p. 945-949, 2006.

PASICK, J. Maedi-Visna Vírus and Caprine ArthritisEncephalitis Vírus: Distinct espécies or quasispecies and its implications for laboratory diagnosis. Canadian Journal of Veterinary Research, v. 62, n. 62, p. 241244, 1998.

PINHEIRO, R. R.; ANDRIOLI, A.; GOUVEIA, A. M. G. Métodos de diagnóstico das lentiviroses de pequenos ruminantes. Circular Técnica 25. Sobral: EMBRAPA Caprinos, 2001b. 8p

PINHEIRO, R. R.; GOUVEIA, A. M. G.; ALVES, F. S. F. Prevalência da infecção pelo vírus da Artrite-Encefalite Caprina no Estado do Ceará, Brasil. Ciência Rural, v. 31 , n. 3, p. 449-454, 2001a.

PINHEIRO, R. R.; GOUVEIA, A. M. G.; ALVES, F. S. F.; ANDRIOLI, A. Perfil de propriedades no estado do Ceará relacionado à presença do lentivírus caprino. Ciência Animal, v. 14, n. 1, p. 29-37, 2004.
PINHEIRO, R.R.; OLORTEGUI, C.D.C.; GOUVEIA, A.M.G.; ARAÚJO, S.C.; ANDRIOLI, A. Desenvolvimento do dot-blot para detecção de anticorpos para o vírus da Artrite Encefalite Caprina. Revista Portuguesa de Ciências Veterinárias, v.101, n.557-558, p.51-56, 2006.

QUINN, P. J.; MARKEY, B. K.; CARTER, M. E.; DONNELLY, W. J.; LEONARD, F. C. Retroviridae. Grupo dos lentivírus de pequenos ruminantes. In:

Microbiologia veterinária e doenças infecciosas. Porto Alegre: Artmed, 2005, p. 346-357.

RÁCZ, M. L. Nomenclatura e classificação dos vírus. In: TRABULSI, L. R.; ALTERTHUM, F. Microbiologia. São Paulo: Atheneu, 2005, p.527-531.

RAdOSTITS, O. H.; GAT, C. C.; BLOOD, D. C.; HINCHCLIFF; K.W. Pneumonia progressiva ovina (Maedi, Maedi-Visna). In:__ Clínica veterinária: Um tratado de doenças dos bovinos, ovinos, suínos, caprinos e eqüinos. 9. ed. Rio de Janeiro: Guanabara Koogan. 2002. p. 1063-1067.

SIGURDSSON, B. Maedi, a slow progressive pneumonie of sheep: an epizoological and pathological study. British Veterinary Journal, v. 110, p. 225-270, 1954.

SOUZA, T.S.; COSTA, J.N.; MARTINEZ, P.M.; PINHEIRO, R.R. Estudo sorológico da Maedi-Visna pelo método de imunodifusão em gel de ágar em rebanhos ovinos de Juazeiro, Bahia, Brasil. Revista Brasileira de Saúde e Produção Animal, v.8, n.4, p.276-282, 2007. 